\title{
Quality and quantity of soil organic matter as affected by the period of organic farming in Sekem farm, Egypt
}

\author{
Reda Ragab Shahin *, Hassan Ahmed Khater
}

Department of Soil Science, Faculty of Agriculture, Cairo University Giza, Egypt

\begin{abstract}
Sekem commercial organic farm was chosen for the present work; it is located at Belbeis 20 $\mathrm{Km}$ northeast of Cairo city which represented sandy soils. Five plots in Sekem farm were chosen to represent different periods of organic farming application, i.e. 0,12,15, 18 and 23 yrs. Surface $(0-20 \mathrm{~cm})$ and subsurface $(20-40 \mathrm{~cm})$ soil samples were collected in both winter and summer season. The collected soil samples were subjected to the dry sieve analysis to determine and separate the dry aggregate size of $<0.25,0.25-0.50,0.50-1.00$ and $1.00-2.00$ $\mathrm{mm}$ diameter. The distributions of total organic carbon were studied in the whole soil and its aggregate fractions. The data showed that total organic carbon significantly increased by increasing the period of organic farming in the surface samples especially in the longest period of organic farming. Total organic carbon was concentrated in the finest aggregate fraction $(<0.25 \mathrm{~mm})$ for both summer and winter seasons and it was also increased by increasing the period of organic farming. The investigation of the humic and fulvic separates using infrared (IR) spectrophotometry, showed the dominance of carboxylic bands in fulvic especially in the subsurface soil samples which indicated its acidic function. Humic separates showed a relative increased in the intensity of aromatic bands as compared to fulvic separates with increasing the period of organic farming.
\end{abstract}

Keywords: Quality, quantity, organic farming period, soil organic carbon.

(C) 2020 Federation of Eurasian Soil Science Societies. All rights reserved

\section{Introduction}

Egypt has a well-developed and still rapidly growing organic farming sector. About 26000 hectares are organically cultivated, accounting for $1.0 \%$ of total of agricultural area of Egypt. Organic production concentrates on about 500 farming enterprises. Most of these farms are desert farms irrigated from the Nile (IFOAM and FIBL, 2006).

Organic farming relies on building up soil organic carbon through crop rotation, green manure, compost to maintain soil productivity, excluding synthetic agrichemical. Organic farming protect the environment by building soil organic carbon and increase carbon sequestration (Bellows, 2002). Field experiments have shown that soil organic carbon content is controlled by change in management via the annual input of organic manures and wastes and the rate at which it decays (Mikha and Rice, 2004). Soil organic carbon contained a15\% liable form while $85 \%$ is in the stable humified form (Pettit, 2000). The relative distribution of the soil humified organic forms i.e. humic and fulvic is mainly controlled by the period of organic farming. Consequently, the present in situ work aimed to investigate the effect of the long term organic farming on the distribution of soil organic carbon and their humic and fulvic characteristics using infrared technique in an organic enterprises at Belbies (SEKEM), Egypt.

$\begin{array}{ll}\text { * } & \text { Reda Ragab Shahin } \\ \text { Hassan Ahmed Khater }\end{array}$ dredashahin@gmail.com
: hakhater2000@yahoo.com 


\section{Material and Methods}

Sekem farm started organic agriculture in 1977. The farm is located in Bilbeis $(20 \mathrm{~km}$ north east of Cairo, $30^{\circ} 09^{\prime} 09 \mathrm{~N}$ and $31^{\circ} 25^{\prime} 46 \mathrm{E}$ elev. $70 \mathrm{~m}$ ). This farm was used as a model farm of the sandy soils in Egypt (the clay range was 3.1-10.2\%). The site of Sekem farms were presented in Figure 1. This farm contains 4 regions with different periods of organic farming practices. Organic farming started since 12, 15, 18, and 23 years for $S_{1}, S_{2}, S_{3}$, and $S_{4}$, respectively, with $S_{0}$ used as control (where no farming was initiated in this sector of the farm). The 12yr treatment, $S_{1}$, is planted with olive trees, for that, samples in this sector were collected from near trees $\left(S_{n}\right)$ and between trees $\left(S_{b}\right)$.Compost was applied to the soil at rate of $20 \mathrm{~m}^{3} \mathrm{yr}^{-1} \mathrm{Fd}^{-1}$.

Sampling was carried out at the end of each growing seasons, in May and October, which represent the end of winter and summer seasons, respectively. Soil samples were collected from both surface soil layer (0-20 $\mathrm{cm})$ and subsurface soil layer $(20-40 \mathrm{~cm})$. Each soil sample was a composite of five sub-samples. The soil samples were air-dried at room temperature, grounded to pass through a $2 \mathrm{~mm}$ sieve and stored prior to analysis.

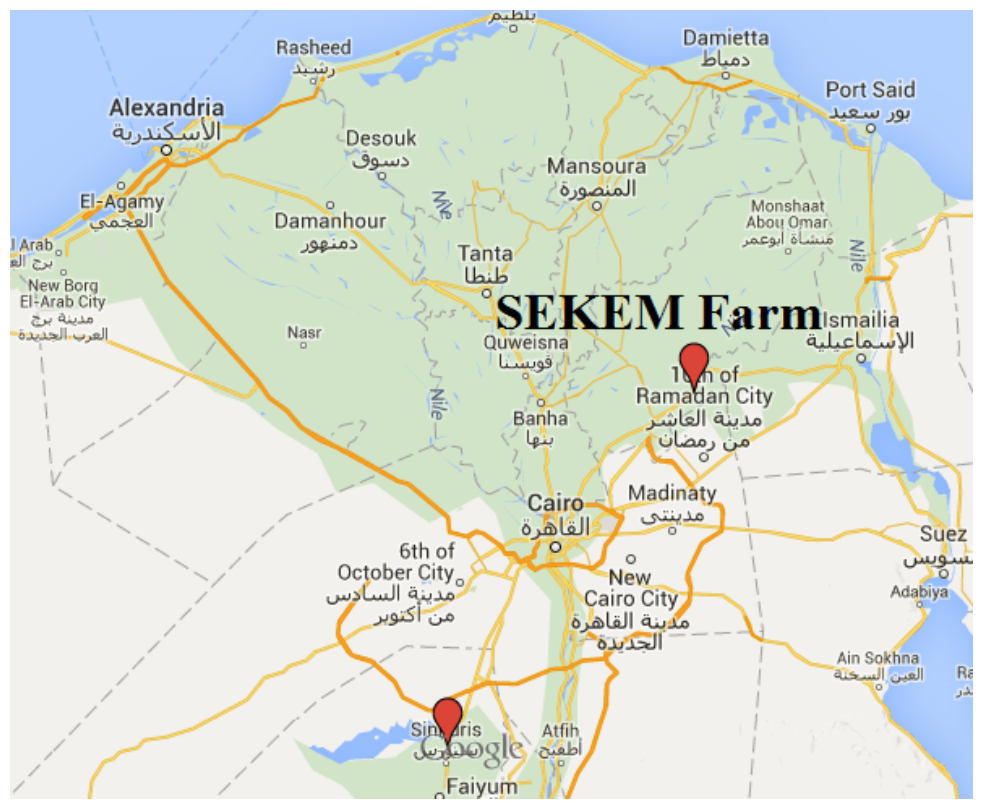

Figure 1. Map of Northern Egypt showing the site of Sekem Farm

The collected soil samples were subjected to the determination of dry aggregate distribution, namely < $0.25 \mathrm{~mm}, 0.25-0.50 \mathrm{~mm}, 0.50-1.00 \mathrm{~mm}$ and $1.00-2.00 \mathrm{~mm}$, using mechanical shaker sieves based on the method of Whalen and Chang (2002).

Total organic carbon was determined in the whole soil samples as well as their dry aggregate separates as described by Walkely-Black method (Nelson and Sommers, 1982).

The classical method of fractionating soil humified organic carbon (HOM) is based on the extraction of organic carbon from soil with caustic alkali and the further subdivision of the extracted material by partial precipitation with mineral acids, and by partial solubility in alcohol. The following groups were obtained: the "humin fraction," insoluble in alkali; the "humic acid fraction," soluble in alkali, insoluble in acid; the "fulvic acid fraction," soluble in alkali, soluble in acid (Hayes, 2006).

After the purification, dried humic and fulvic acid were subjected to the FT-IR examinations by a JesCo FTS 460 + single beam using the $\mathrm{KBr}$ technique $(2 \mathrm{mg}$ sample in $150 \mathrm{mg} \mathrm{KBr}$ ) (Celi et al., 1997; Eleerbrock et al., 1999) to obtain absorption spectra of both acids extracts (range of wave number $3900-400 \mathrm{~cm}^{-1}$ ). All spectra were obtained under the same resolution $\left(1 \mathrm{~cm}^{-1}\right)$ and measurement conditions.

\section{Results and Discussion}

\section{Distribution of soil organic carbon as affected by organic farming periods}

Table 1 showed an increase in total organic carbon (TOM) with the increase in cultivation period in Sekem farm for both surface and subsurface layers in winter and summer seasons. The magnitude of TOM increase was much higher in the surface layer, as it reached after 23 yrs of cultivation almost 18 times that in the beginning, while it was only 5 times in the subsurface layer after 23 yrs of cultivation, due to the surface application of organic compost and plant residues. The application of organic manures for ten years caused superior increses in total SOC as compare to the applications of $\mathrm{n}$ and $\mathrm{P}$ fertilizers (Mikha and Rice, 2004). 
Table 1. Total organic carbon changes in surface and subsurface with different periods of organic farming in winter and summer seasons in Sekem farm.

\begin{tabular}{clccccc}
\hline \multirow{2}{*}{ Season } & $\begin{array}{l}\text { Depth } \\
(\mathrm{cm})\end{array}$ & $\mathrm{S}_{0}$ & $\mathrm{~S}_{1}$ & $\mathrm{~S}_{2}$ & $\mathrm{~S}_{3}$ & $\mathrm{~S}_{4}$ \\
\cline { 2 - 7 } & $0-20$ & 560 & 6132 & 7203 & 8119 & 10789 \\
\multirow{2}{*}{ Winter } & $20-40$ & 734 & 1162 & 1630 & 1348 & 3956 \\
\hline \multirow{2}{*}{ Summer } & $0-20$ & 579 & 5978 & 7122 & 5885 & 10380 \\
& $20-40$ & 767 & 1032 & 2516 & 2482 & 3894 \\
\hline
\end{tabular}

$\mathrm{S}_{0}=$ control; $\mathrm{S}_{1}=12 \mathrm{yrs} ; \mathrm{S}_{2}=15 \mathrm{yrs} ; \mathrm{S}_{3}=18$ yrs and $\mathrm{S}_{4}=23$ yrs.

Rochette and Gregorich (1998) stated that at the end of the growing season @ 50\% of carbon of the applied organic manure was remained in soil. Soil Organic carbon could be doubled by annual application rate of 2.0 tons carbon from organic amendments (Gerzabek et al., 2001).

Buildup of soil carbon could only be attained when Carbon input is larger than decomposition rate. Soil management processes such as continuous cropping, cover crop and or rotation includes perennial leguminous crops as well as continuous addition of manures certainly guarantee carbon buildup in the soil. Grant et al. (2001) stated that two year rotation was not sufficient to raise SOC in the uppermost topsoil (15 $\mathrm{cm}$ depth) in the absence of organic manuring.

Relationship between long term organic farming and TOM was illustrated in Figure 2. Total organic carbon (TOM) was highly significant relationship related with time for Sekem soil $\left(\mathrm{R}^{2}=0.996\right.$ and 0.908 for winter and summer seasons, respectively). High $\mathrm{R}^{2}$ was also observed for the subsurface layer ( 0.782 and 0.851 under winter and summer seasons, respectively. This relative decrease in $\mathrm{R}^{2}$ was due to the lower amount of organic compost and plant residual that could reached the subsurface layer.
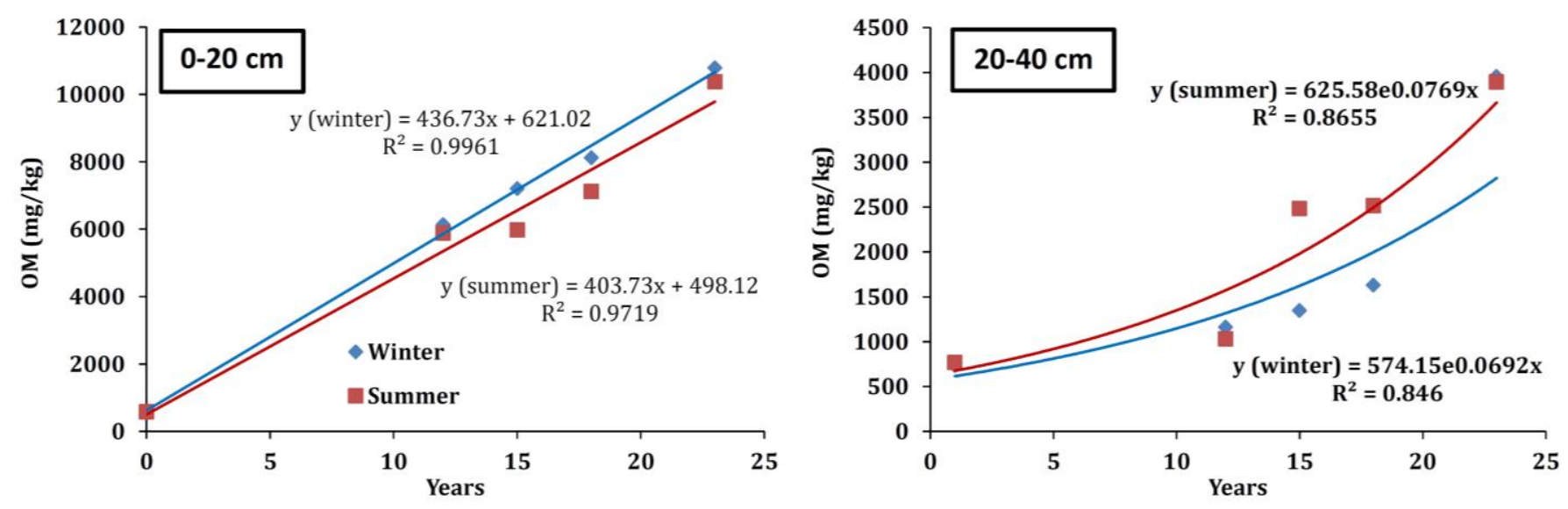

Figure 2. Relationship of OM with time in Sekem farm for winter and summer seasons in surface $(0-20 \mathrm{~cm})$ and subsurface $(20-40 \mathrm{~cm})$ layers

\section{Distribution of TOM in dry sieve separates with time}

Figure 3 represents TOM distribution in dry sieve separates for Sekem farm which indicated that the highest TOM content was recorded in the finest fraction $(<0.25 \mathrm{~mm})$ and it increased with increasing period of organic farming. On the other hand, the coarse separates $(1.0-2.0 \mathrm{~mm})$ contained the lowest TOM \%. This trend was consistently found in winter and summer seasons for the surface and subsurface layers of Sekem farm. Desjardins et al. (1994) confirmed that $\mathrm{C}_{\text {org }}$ concentrations increased with decreasing soil particle size. In addition, Aoyama et al. (1999) stated that particulate and mineral-associated organic carbon in waterstable aggregates were increased by increasing the rate of organic manure applications.

This could be due to that the smallest size separate has the largest quantity of clay size particles which indicated that organic compounds had been stabilized through the formation of strong clay-organic complexes (Gonzalez and Laird, 2003). In addition, the complexation of light molecular weight (rapid decomposable) organic compounds by clay and silt soil particles also maintain its stability in the soil (Sørensen, 1972). Gerzabek et al. (2001) stated that siltsoil particles had medium capacity to retain soil organic carbon while clay ones slowed down OC turnover rates as it shows the maximum capacity for fixing organic compounds (Buyanovsky et al. 1994). 

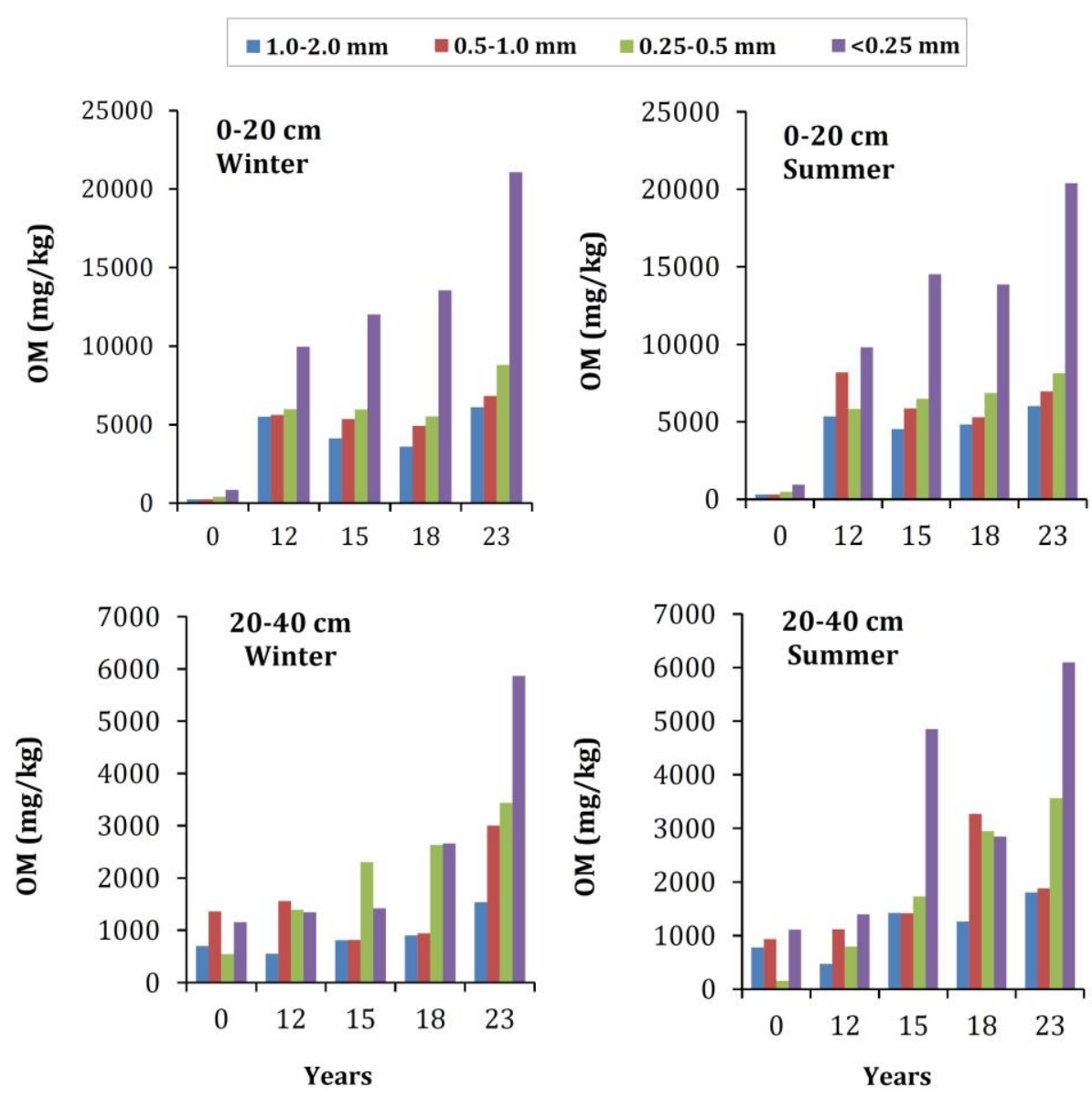

Figure 3. Distribution of OM through dry sieve separates for Sekem in surface and subsurface samples under winter and summer seasons.

\section{Infrared (IR) investigation of humus fractions in Sekem organic farm as affected by organic farming periods}

Humic and fulvic acids were separated from the surface $(0-20 \mathrm{~cm})$ and subsurface $(20-40 \mathrm{~cm})$ soil samples collected from Sekem (23 yrs) and the compost that continuously used as an organic fertilizer. The obtained humic and fulvic acids separates were subjected to IR examination which could be discussed as follows:

\section{IR-characteristics of fulvic acid separate from Sekem farm}

Figure 4 represents IR-spectra of fulvic acid separates and the main absorption bands are presented in Table 2. IR-bands were assigned according to Sánchez-Monedero et al. (2002). IR-spectra of fulvic acid exhibit a broad band at 3459-3437 $\mathrm{cm}^{-1}$ (stretching of $\mathrm{O}-\mathrm{H}$ bonds), medium band around $2361-2315 \mathrm{~cm}^{-1}$ (stretching of $\mathrm{H}-\mathrm{N}$ bonds). A well defined band around $1640 \mathrm{~cm}^{-1}$ was assigned to aromatic $\mathrm{C}=\mathrm{C}$ stretching, $\mathrm{C}=\mathrm{O}$ of ketones and carboxylate ions. A couple of peaks around $1430 \mathrm{~cm}^{-1}$ due to aliphatic $\mathrm{C}-\mathrm{H}$ stretching and peaks around $1030 \mathrm{~cm}^{-1}$ due to $\mathrm{C}-0$ stretching bond of polysaccharides were also assigned.

Table 2. Corrected relative transmission (T\%) for the main IR bands of fulvic acid separates from Sekem organic farm

\begin{tabular}{|c|c|c|c|c|c|c|}
\hline \multirow{2}{*}{ Bond } & \multicolumn{2}{|c|}{ compost } & \multicolumn{2}{|c|}{ Surface $(0-20 \mathrm{~cm})$} & \multicolumn{2}{|c|}{ Subsurface $(20-40 \mathrm{~cm})$} \\
\hline & band & $\mathrm{T} \%$ corr. & band & $\mathrm{T} \%$ corr. & band & T\% corr. \\
\hline & \multicolumn{6}{|c|}{ Sekem FA 23 years } \\
\hline OH st.* & 3455 & 7 & 3437 & 2 & 3439 & 1 \\
\hline $\mathrm{H}-\mathrm{N}$ st. & 2361 & 96 & 2317 & 90 & 2318 & 75 \\
\hline \multirow[t]{2}{*}{$\mathrm{C}=\mathrm{C}$ st. } & 2066 & 95 & 2069 & 85 & 2087 & 77 \\
\hline & 1868 & 98 & - & - & - & - \\
\hline \multirow[t]{2}{*}{$\mathrm{C}=\mathrm{C}$} & 1639 & 48 & 1638 & 25 & 1638 & 17 \\
\hline & 1517 & 87 & 1520 & 90 & - & - \\
\hline C-H aliph.** & 1458 & 91 & 1460 & 85 & 1459 & 89 \\
\hline COO st. & 1420 & 92 & 1400 & 86 & 1400 & 88 \\
\hline $\mathrm{KBr}$ & 574 & 55 & 552 & 32 & 572 & 26 \\
\hline
\end{tabular}

${ }^{*}$ st.= Stretching band and ${ }^{* * a l i p h . ~=~ A l i p h a t i c ~ b a n d . ~}$ 
Relative intensities (transmission T \%) of the obtained IR-bands had been corrected to $100 \%$ for all IRspectra in order to make comparisons among them. Table 3 represents the corrected transmission (T \%) of IR-bands for compost, surface and subsurface fulvic acid separates. It is well known that the absorbance (A) not transmittance ( $\mathrm{T} \%$ ) which expressing the intensity of a specific bond in the examined complex according to Beer-Lambert law (Robincon, 1996). This means that the higher the T\% the lower the absorbance and the lower the intensity of the relevant band. Therefore, the obtained intensity differences showed that fulvic acid separates had higher contents of aliphatic and carboxylic $\mathrm{H}$-bonded $\mathrm{C}=\mathrm{O}$ and amides. The higher content of aliphatic and carboxylic groups in compost fulvic acid separates was widely reported in the literature (Gigliotti et al., 1990), which indicated the higher acidity nature of fulvic acid separates. With respect to the relative transmission (T\%) of the IR-bands around 2069 and $1640 \mathrm{~cm}^{-1}$ (aliphatic C=C and carboxylic C=0 stretching), it was decreased from 96 and $48 \%$ in Sekem compost to 90 and $25 \%$ in the surface layer then reached 75 and $17 \%$, respectively, in the subsurface layer. This indicated that aliphatic $\mathrm{C}=\mathrm{C}$ and carboxylic $\mathrm{C}=\mathrm{O}$ bonds had the lowest absorption intensity in Sekem compost-FA then increased in the surface-FA while the highest intensity of these groups was found in FA separates from subsurface layer. This could be attributed to the progress of FA polymerization which increased double bond intensity through the advancement of the compost decomposition process (Plaza et al., 2007; Abouelwafa et al., 2008). In addition, absorption intensity of carboxylic band was much higher than that of aliphatic $\mathrm{C}=\mathrm{C}$ bond which indicated the acidic nature of fulvic acid. On the other hand, the intensity around $1520 \mathrm{~cm}^{-1}$ (aromatic $\mathrm{C}=\mathrm{C}$ ), $1460 \mathrm{~cm}^{-1}$ (aliphatic C-H) and $1420 \mathrm{~cm}^{-1}$ (COOH stretching) were slightly changed which indicated that the proportions of these bonds didn't show major differences in Sekem compost and amended soil.

\section{IR-characteristics of humic acid separated from Sekem farm}

Figure 5 represents IR-spectra of humic acid separates from Sekem compost, soil surface and subsurface soil layers. IR-spectra of humic acid separates were significantly different from these of FA separates. Hydroxyl $\mathrm{O}-\mathrm{H}$ stretching was shifted to around $3405 \mathrm{~cm}^{-1}$, new aliphatic $\mathrm{COOH}$ group was developed at $2927 \mathrm{~cm}^{-1}$, and new aromatic C-C and C-O-C bonds were developed at $1227 \mathrm{~cm}^{-1}$ and $1033 \mathrm{~cm}^{-1}$ bands. Additional group of aromatic bands were developed at $1628 \mathrm{~cm}^{-1}$ ( $\mathrm{C}=\mathrm{C}$ aromatic), and 1513 and $1415 \mathrm{~cm}^{-1}$ (C-H aromatic).

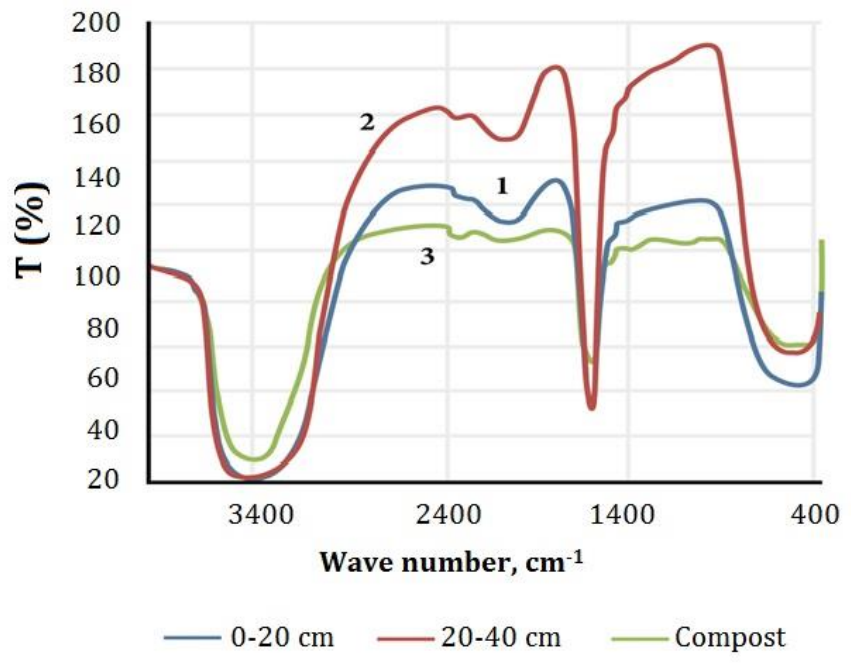

Figure 4. IR-spectra of fulvic acid separates of compost, surface $(0-20 \mathrm{~cm})$ and subsurface $(20-40 \mathrm{~cm})$ layers of Sekem organic farm cultivated for 23 yrs.

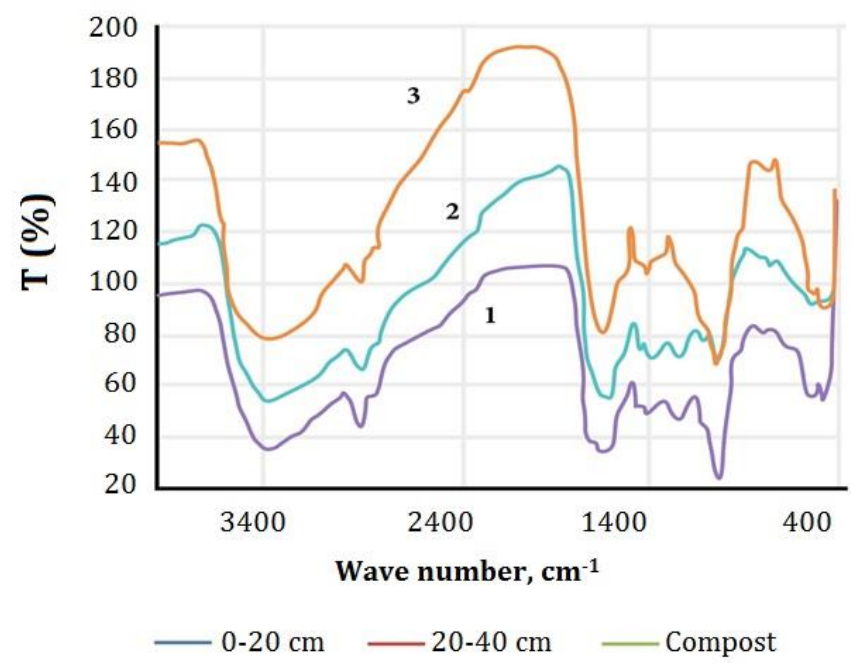

Figure 5. IR-spectra of humic acid separates of compost, surface $(0-20 \mathrm{~cm})$ and subsurface $(20-40 \mathrm{~cm})$ layers of Sekem organic farm cultivated for 23 yrs.

Regarding the relative intensities of the HA IR-spectra, Table 3 showed a relative increase in the intensity of the aromatic bands (from 16 to 50\%) which indicated the abundance of aromatic compounds in humic acid separates as compared to fulvic acid separates which is in agreement with finding of Lguirati et al. (2005) and Guignard et al. (2005).

The relative intensity of $\mathrm{OH}$ bond (phenyl and alcohol) was the highest in Sekem compost then decreased in the surface and subsurface soil layer which indicated the polymerization to form humic acid. The relative intensities of HA separates was significantly higher in Sekem compost compared which may confirmed by the high content of stable OM\% in Sekem by increasing the period of organic farming. 
Table 3. Corrected relative transmission (T\%) for the main IR bands of humic acid separates from Sekem organic farm

\begin{tabular}{|c|c|c|c|c|c|c|}
\hline \multirow{2}{*}{ bond } & \multicolumn{2}{|c|}{ compost } & \multicolumn{2}{|c|}{ Surface $(0-20 \mathrm{~cm})$} & \multicolumn{2}{|c|}{ Subsurface $(20-40 \mathrm{~cm})$} \\
\hline & band & T\% Corr. & band & T\% corr. & band & $\mathrm{T} \%$ corr. \\
\hline & \multicolumn{6}{|c|}{ Sekem HA 23 years } \\
\hline OH st.* & 3404 & 14 & 3406 & 34 & 3405 & 28 \\
\hline Ali. C-H st. & 2929 & 31 & 2927 & 42 & 2927 & 38 \\
\hline $\mathrm{N}-\mathrm{H}_{2}$ st. & 2367 & 86 & 2368 & 88 & - & - \\
\hline $\mathrm{C}=\mathrm{N}, \mathrm{C}=\mathrm{O}$ & - & - & 1706 & 36 & - & - \\
\hline \multirow[t]{2}{*}{$\mathrm{C}=\mathrm{C}$ aro.** } & 1648 & 16 & 1628 & 32 & 1626 & 28 \\
\hline & - & - & 1513 & 50 & - & - \\
\hline $\mathrm{CH}_{2}$ aliph. & 1456 & 36 & 1456 & 48 & 1455 & 44 \\
\hline \multirow[t]{2}{*}{ C-H aro.*** } & 1386 & 34 & 1415 & 47 & - & - \\
\hline & - & - & 1227 & 45 & 1227 & 42 \\
\hline $\mathrm{C}-\mathrm{O}-\mathrm{C}$ aro. & 1031 & 8 & 1033 & 23 & 1033 & 42 \\
\hline $\mathrm{KBr}$ & 522 & 27 & 525 & 52 & 531 & 58 \\
\hline
\end{tabular}

*st.= Stretching band; ${ }^{* *}$ aliph. = Aliphatic band and ${ }^{* * *}$ aro. $=$ Aromatic band

In conclusion, total organic carbon TOM significantly increased by increasing the period of organic farming in the surface samples especially in the longest period of organic farming. Total OM was concentrated in the finest aggregate fraction $(<0.25 \mathrm{~mm})$ for both summer and winter seasons and it was also increased by increasing the period of organic farming. The investigation of the humic and fulvic separates using infrared (IR) spectrophotometery, showed the dominance of carboxylic bands in fulvic especially in the subsurface soil samples which indicated its acidic function. Humic separates showed a relative increased in the intensity of aromatic bands as compared to fulvic separates with increasing the period of organic farming.

\section{References}

Abouelwafa, R., Amir, S., Souabi, S., Winterton, P., Ndira, V., Revel, J.C.,Hafidi, M., 2008. The fulvic acid fraction as it changes in the mature phase of vegetable oil-mill sludge and domestic waste composting. Bioresource Technology 99(14): 6112-6118.

Aoyama, M., Angers, D.A., N'Dayegamiye, A., 1999. Particulate and mineral-associated organic carbon in water-stable aggregates as affected by mineral fertilizer and manure applications. Canadian Journal of Soil Science 79(2): 295302.

Bellows, B., 2002. Protecting water quality on organic farms. Available at [Access date: 03.03.2019]: http://edepot.wur.nl/115572

Buyanovsky, G.A., Aslam, M., Wagner, G.H., 1994. Carbon turnover in soil physical fractions. Soil Science Society of America Journal 58(4): 1167-1173.

Celi, L., Schnitzer, M., Nègre, M., 1997. Analysis of carboxyl groups in soil humic acids by a wet chemical method, Fourier-Transform infrared spectrometry and solution-state carbon-13 nuclear mag $\neg$ netic resonance. A comparative study. Soil Science 162(3): 189-197.

Desjardins, T., Andreux, F., Volkoff, B., Cerri, C.C., 1994. Organic carbon and ${ }^{13} \mathrm{C}$ contents in soils and soil size-fractions, and their changes due to deforestation and pasture installation in eastern Amazonia. Geoderma 61(1-2): 103118.

Eleerbrock, R.H., Höhn, A., Rogasik, J., 1999. Functional analysis of soil organic matter as affected by long-term manurial treatment. European Journal of Soil Science 50(1): 65-71.

Gerzabek, M.H., Haberhauer, G., Kirchmann, H., 2001. Soil organic matter pools and carbon-13 natural abundances in particle-size fractions of a long-term agricultural field experiment receiving organic amendments. Soil Science Society of America Journal 65(2): 352-358.

Gigliotti, G., Businelli, D., Giusquiani, P.L., 1999. Composition changes of soil humus after massive application of urban waste compost: a comparison between FT-IR spectroscopy and humification parameters. Nutrient Cycling in Agroecosystems 55: 23-28.

Gonzalez, J.M., Laird, D.A., 2003. Carbon sequestration in clay mineral fractions from ${ }^{14}$ C-labeled plant residues. Soil Science Society of America Journal 67(6): 1715-1720.

Grant, R.F., Juma, N.G., Robertson, J.A., Izaurralde, R.C., McGill, W.B., 2001. Long-term changes in soil carbon under different fertilizer, manure, and rotation: Testing the mathematical model ecosys. with data from the Breton plots. Soil Science Society of America Journal 65(1): 205-214.

Guignard, C., Lemée, L., Amblès, A., 2005. Lipid constituents of peat humic acids and humin. Distinction from directly extractable bitumen components using TMAH and TEAAc thermochemolysis. Organic Geochemistry 36(2): 287297. 
Hayes, M.H.B., 2006. Solvent systems for the isolation of organic components from soils. Soil Science Society of America Journal 70(3): 986-994.

IFOAM and FiBL, 2006. International Federation of Organic Agriculture Movements (IFOAM), Bonn \& Research Institute of Organic Agriculture (FiBL), Frick. The World of Organic Agriculture. Statistics and Emerging Trends. pp. 2735. Available at [Access date: 03.03.2019]: https://orgprints.org/5161/

Lguirati, A., Ait Baddi, G., El Mousadik, A., Gilard, V., Revel, J.C ., Hafidi, M., 2005. Analysis of humic acids from aerated and non-aerated urban landfill composts. International Biodeterioration \& Biodegradation 56(1): 8-16.

Mikha, M.M., Rice, C.W., 2004. Tillage and manure effects on soil and aggregate-associated carbon and nitrogen. Soil Science Society of America Journal 68(3): 809-816.

Nelson, D.W., Sommers, L.E., 1982. Total carbon, organic carbon, and organic matter. In: Methods of Soil Analysis, Part 2. Chemical and Microbiological Properties. Page, A.L, Miller, R.H., Keeney, D.R. (Eds.). 2nd Edition. Agronomy Monograph, vol. 9. American Society of Agronomy - Soil Science Society of America, WI, USA. pp. 593-579.

Pettit, R..E., 2000. Organic carbon, humus, humate, humic acid, fulvic acid, and humin. Available at [Access date: 03.03.2019]: http://www.naturalagsolutions.com/uploads/1/4/7/2/14721182/_organicmatter.pdf

Plaza, C., Senesi, N., Brunetti, G., Mondelli, D., 2007. Evolution of the fulvic acid fractions during co-composting of olive oil mill wastewater sludge and tree cuttings. Bioresource Technology 98(10): 1964-1971.

Robincon, J.W., 1996. Introduction. In: Atomic Spectroscopy. Robincon, J.W. (Ed.). Second edition, Revised and Expanded. Marcel Dekker, Inc. New York, USA. pp. 1-64.

Rochette, P., Gregorich, E.G., 1998. Dynamics of soil microbial biomass C, soluble organic C, and $\mathrm{CO}_{2}$ evolution after three years of manure application. Canadian Journal of Soil Science 78(2): 283-290.

Sánchez-Monedero, M.A., Cegarra, J., García, D., Roig, A., 2002. Chemical and structural evolution of humic acids during organic waste composting. Biodegradation 13: 361-371.

Sørensen, L.H., 1972. Stabilization of newly formed amino-acid metabolites in soil by clay minerals. Soil Science 114(1): 5-11.

Whalen, J.K., Chang, C., 2002. Macroaggregate characteristics in cultivated soils after 25 annual manure applications. Soil Science Society of America Journal 66(5): 1637-1647. 